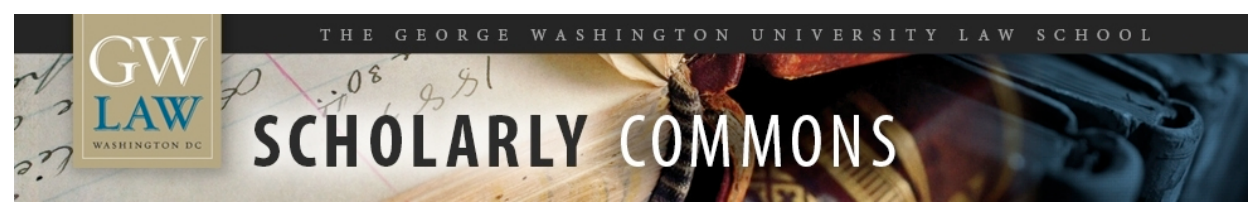

\title{
Regulation and the Courts: Judicial Review in Comparative Perspective
}

\author{
Francesca Bignami \\ George Washington University Law School, fbignami@law.gwu.edu
}

Follow this and additional works at: https://scholarship.law.gwu.edu/faculty_publications

Part of the Law Commons

\section{Recommended Citation}

Bignami, Francesca, Regulation and the Courts: Judicial Review in Comparative Perspective (2016). COMPARATIVE LAW AND REGULATION: UNDERSTANDING THE GLOBAL REGULATORY PROCESS, Francesca Bignami \& David Zaring eds., Edward Elgar, 2016 ; GWU Law School Public Law Research Paper No. 2016-50; GWU Legal Studies Research Paper No. 2016-50. Available at SSRN: http://ssrn.com/ abstract $=2845912$

This Article is brought to you for free and open access by the Faculty Scholarship at Scholarly Commons. It has been accepted for inclusion in GW Law Faculty Publications \& Other Works by an authorized administrator of Scholarly Commons. For more information, please contact spagel@law.gwu.edu. 


\title{
Regulation and the courts: judicial review in comparative perspective
}

\section{Francesca Bignami}

\begin{abstract}
Chapter 10 in: Comparative Law and Regulation: Understanding the Global Regulatory Process
\end{abstract}
(Francesca Bignami \& David Zaring eds., Edward Elgar 2016)

\section{INTRODUCTION}

The public law of government intervention in economy and society has a long history that has been driven by the politics of democratization and state formation and that has had profound consequences for the legitimacy and effectiveness of the contemporary administrative state. In large part, this public law has been identified with judicial review and the courts: on what grounds will a court find the decisions of the political and administrative organs of the state to be unlawful? At the same time, a considerable body of comparative scholarship has sought to capture variation in judicial redress in different legal systems. The premise of much of the comparative scholarship is that liberal societies can share roughly similar commitments to principles such as the rule of law and fundamental rights but can seek to safeguard such principles through different types of courts and legal doctrines. The thought is that, by appreciating the differences, it is possible to obtain a better understanding of the legal and political operation of government policymaking both at home and abroad and to engage in constructive thinking on the proper design of law, courts, and the administrative state.

This chapter is designed as both a review of the comparative literature on judicial review and as an original contribution to that literature. It presents two important contrasts that have been drawn between systems of public law in western countries and proposes a third based on 
my own research. The purpose is to develop a comparative blueprint that can help the reader navigate public policymaking and the courts in different jurisdictions across the globe. While the three classifications covered in this chapter overlap in certain respects, they are mostly complementary, not competing, and therefore taken together they create a multi-dimensional and fairly complete picture of the landscape of judicial review. Most of the discussion applies broadly to the activities of the administrative state, not specifically to the regulatory function, since the public law of most countries does not expressly draw such distinctions. Mindful, however, of the larger purposes of this volume, the chapter also highlights the implications for regulation where appropriate.

The chapter proceeds as follows. The next section presents one of the first and most enduring contrasts that has been drawn between systems of public law and judicial review: judicial review of administrative action by the ordinary courts in the English common law and by a special body (Conseil d'Etat) connected to the executive branch in the French droit administratif. Initially identified by the English scholar A.V. Dicey in the late nineteenth century, the common law-droit administratif divide has since been re-examined and re-assessed by several generations of comparative scholars (Dicey, 1885; Goodnow, 1893; Garner, 1924; Schwartz, 1949; Mitchell, 1965; Brown and Garner, 1967; Breyer, 1993; Brown and Bell, 1998). The following section turns to the difference between the litigious and formal American system of law and public policy and the informal and discretionary European policy process. These categories of difference are largely the brainchild of Robert Kagan and his theory of American "adversarial legalism" (1991, 1994, 1997, 2001), although they have also been developed in rational-choice scholarship on policymaking in the American presidential system of government and European parliamentary systems (Moe and Caldwell, 1994; Epstein and O'Halloran, 1999: 242-44; Thies, 2001; Jensen and McGrath, 2011; Rose-Ackerman et al., 2015; Rose-Ackerman et al., this volume). In the last section, I propose a third major contrast between systems of public law in the regulatory domain: judicial review informed by theories of fundamental economic and social rights in Europe, as illustrated by the doctrines of proportionality and equality, and judicial review designed to promote a democratic and participatory administrative process in the United States, what I call the "ballot-box democracy" paradigm of public law. I argue that this divide has 
the potential to extend to other jurisdictions in light of the global diffusion of written constitutions and constitutional courts (Ginsburg, 2008). In exploring the three classifications of national systems of judicial review, each section examines their historical origins and draws out their normative implications. Each section also considers the implications of these classifications-developed in the more general context of the administrative state-specifically for regulation, which is defined in the sense of this book as rule-based governance by specialized administrative authorities under the supervision of the legislature, the political executive, and the courts.

Before continuing, one point of clarification is in order. The first question that is likely to come to mind is where this discussion of judicial review fits in the conventional breakdown of the legal discipline-constitutional or administrative law? Although the distinction may seem obvious, as it turns out, different jurisdictions and the different subfields themselves employ their own criteria to delineate what law is covered. While constitutional lawyers tend to include anything that is contained in a particular source of law, that is, the Constitution, administrative lawyers focus on the law that is applied to a particular type of government institution, that is, public administration. But the focus of this volume and chapter is neither a legal source nor a government institution. Rather it is a particular domain of state activity, i.e., regulation, which can involve both legislative and administrative action, and how courts intervene in that domain, which can be based upon both constitutional and secondary sources of law. With the exception of the next section, therefore, this chapter covers both constitutional and administrative law. The next section on the early common law-droit administratif divide is the exception because it focuses exclusively on administrative law. The reason for the early emphasis on administrative law is fairly simple: until World War II, administrative law was the only form of litigated public law in most western jurisdictions, and even after World War II, when constitutional courts were established in a number of European countries, it was decades before a thick law and practice of constitutional adjudication took hold (Stone, 1992: 225-53). 


\section{COMMON LAW VERSUS DROIT ADMINISTRATIF}

In the annals of comparative public law, the difference between administrative litigation in the common law and the droit administratif traditions is one of oldest and most enduring sources of debate and scholarship. In the liberal model that took hold across Europe in the late nineteenth century, the concept of the rule of law was central (Mannori and Sordi, 2001; Stolleis, 2001). The existence of a private sphere of liberty, separate from public power, was to be guaranteed by a system of government that respected the rule of law: individuals enjoyed rights independent of the state, any state action had to be authorized by law, and citizens had to be able to go to the courts to obtain relief against overreaching state action. Yet despite the spread of the political philosophy of liberalism, there were fundamental differences in how the rule of law was operationalized in England and France, two of the most powerful nation states of the time. As the English scholar A.V. Dicey famously pointed out in Law of the Constitution (1885), France had a separate system of justice for obtaining redress against government actors in which officials had to be sued in a special court (Conseil d'Etat) and according to a special set of legal doctrines. By contrast, government officials in England were held accountable to the law before the same courts and under the same legal principles as private individuals. The common law model, in Dicey's analysis, was clearly the better guarantor of the rule of law and the rights of individuals (Allison, 1996: 11; Lindseth, 2005). It was also a reflection of a deep-rooted, historical divide between the limited government and liberty-driven tradition of the common law and the absolutism of the Continent which, in Dicey's view, prevailed even in the face of the political transformations of the nineteenth century. In other words, the common law model was what a contemporary comparativist might call the "better" law (Zweigert and Kötz, 1998: 47), not just because of the niceties of legal forms, organization, and remedies but because it was the mark of a superior legal tradition deeply committed to individual liberties, limited government, and the rule of law.

The common law-droit administratif divide pronounced by Dicey has been both highly influential and enormously controversial (Allison, 1996: 19-23). Perhaps the most widely accepted aspect of Dicey's analysis has been his view of the historical origins of the two models. 
As with many other differences between the English common law and the law of continental Europe, the timing of the centralization of state power appears to have been critical. Compared with continental Europe, political power was consolidated in the hands of the monarchy relatively early in England, in some accounts as far back as the Norman Conquest (Ertman, 1997). This early state took the form of a centralized system of law and courts but a decentralized administration that rested on local dignitaries serving on various lay bodies and as justices of the peace, as the office would later be called (Lovell, 1962; Van Caenegem, 1998). Although industrialization and other social and economic pressures produced significant growth in the administrative capacity of the state, the early configuration of centralized, common law courts and decentralized administration remains essential to understanding the institutions of the British state (Cassese, 2010). This is particularly true with respect to the absence of a specialized system of administrative justice. At various junctures, the common law bar successfully resisted pressure to transfer power over public litigation from the common law courts to an alternative set of courts that would have had exclusive jurisdiction over claims against public actors. ${ }^{1}$

In France, by contrast, the consolidation of state power occurred almost four centuries later, at a time when it was both technologically possible and politically necessary to develop a centralized administration and a special jurisdiction to hear complaints against that administration. As has been recounted by others, the origins of the Conseil d'Etat can be found in the Ancien Régime and absolutism (Mannori and Sordi, 2001; Zoller, 2008). During the 1600s and 1700s, royal administrators in the provinces, known as intendants, acquired greater powers and administrative capacity as the monarchy sought to assert control over the nobility and other local elites. One major obstacle, however, to this form of centralized administration was the regional courts (Parlements). Composed of local dignitaries, the Parlements used their powers to refuse the registration of royal ordinances, thereby denying them effect, and to hear complaints against the royal administrators. In response to this interference, the monarchy sought to give a special, central body known as the King's Council (Conseil du Roi) exclusive jurisdiction to hear cases against the administration. The Parlements, however, persisted in asserting jurisdiction

\footnotetext{
${ }^{1}$ Perhaps the best known episode is the defeat of the Star Chamber during the English Revolution (Mitchell, 1965: 96-97).
} 
over claims against the intendants and conflict between the two sets of judicial authorities continued until the Revolution.

After the Revolution, administrative disputes continued to be heard by a special jurisdiction connected to the executive branch, but now without competition from the courts. The decision to establish the Conseil d'Etat, in many respects the successor to the Conseil du Roi, was the reflection of two powerful ideological threads running through the Revolution. The first was the delegitimization of courts because of their association with the special privileges and powerful local elites of the Ancien Régime. The second was the glorification of the general will and the republican form of government and the desire to shield the political expression of the general will, in the legislature and the administration, from the meddling of the courts. The oftrepeated aphorism that "juger est encore administrer" (to judge is still to administer) expresses the distinctive separation of powers doctrine espoused during the Revolution and afterwards: the balance between the three powers was at greatest risk from the judicial branch and therefore oversight of the administration could not be entrusted to the ordinary courts but had to be vested in a special body connected to the executive. In sum, in both the Ancien Régime and the Revolution, centralized administration and a specialized jurisdiction to oversee administration were essential to the consolidation of political authority, at first in the name of absolute monarchy and later in the name of republicanism.

The configuration of administrative justice has changed considerably since Dicey first wrote but there are still important differences in how challenges to administrative action are brought in England and France and, more broadly, the many jurisdictions that have been influenced by the common law and droit administratif models. ${ }^{2}$ To understand these differences, it is necessary to briefly trace the evolution of the two systems. When it was originally established in 1804, the Conseil d'Etat resembled more closely an executive advisory body than a full-fledged court. By the end of the nineteenth century, however, the reverse was the case: its procedure had been judicialized, it had acquired mandatory jurisdiction over disputes brought against the administration, its judgments had become final and were no longer styled as recommendations

\footnotetext{
${ }^{2}$ Australia, New Zealand, India, Ireland, and the United States belong to the common law tradition while Belgium, the Netherlands, Luxembourg, Italy, Greece, Turkey, Lebanon, Egypt, Columbia, Morocco, Algeria, and Senegal belong to the droit administratif tradition (Bignami, 2011: 92).
} 
to the head of state, and its members had, as a matter of custom, acquired independence from the government (Brown and Bell, 1998: 47-50). In a set of developments that occurred somewhat later, the English system of administrative justice became more specialized. Beginning in the early 1900s, administrative tribunals were established within the bureaucracy to hear individual claims in areas such as welfare policy and labor and employment law (Cane, 2009: 30). Although tribunal decisions were technically subject to review by the common law courts, the system of administrative tribunals was largely free-standing, with very little interference, even on points of law, from the ordinary courts. Just as important, a number of changes have been made to the common law system of access to justice, discovery, and remedies to facilitate challenges against administrative authorities, resulting in a litigation model tailored specifically to obtaining redress against public actors (Allison, 1996: 23-29).

Despite these transformations, there remain a couple of key differences that fall into roughly two categories-organizational and doctrinal. On the organizational front, in the common law, challenges against the state are heard in the last resort by judges with the same training, professional experience, and institutional safeguards as all other members of the judiciary. These judges hear a variety of cases and enjoy all the traditional guarantees of judicial independence, namely life tenure and removal from office only for serious disciplinary reasons. By contrast, in the droit administratif, administrative litigation is brought before the Conseil $d^{\prime}$ Etat, which is composed of high-status executive branch officials who not only decide cases (adjudicatory function) but also give advice on proposed legislation and administrative rules (regulatory function) and who regularly rotate through important departments within the government (Fromont, 2006: 121-22). ${ }^{3}$ Unlike the judiciary, the members of the Conseil d'Etat do not enjoy a formal guarantee of permanence in office (inamovibilité), meaning that it is theoretically possible (but practically unthinkable) that they can be transferred from one post to another for any reason and not only in the case of misconduct. Training is different from the personnel selection system for the judiciary. Recruits attend the same high-status institutions of higher learning (grandes écoles) as other administrative and political elites, which are entirely

\footnotetext{
${ }^{3}$ Since 1953, there has also existed a full-fledged system of lower administrative courts that are charged with hearing administrative litigation in the first instance and on appeal, and that operate somewhat differently from the Conseil d'Etat (Morand-Deviller, 2013: 48-53).
} 
separate from the university system and the specialization school for judges. They are selected for the Conseil d'Etat based on the final exam administered by the École Nationale d'Administration, the last, sequentially, of these high-status educational institutions. In other words, by virtue of their educational background and their career paths, the state officials that adjudicate administrative disputes in France identify less with the career judiciary and more with the upper echelons of the state administration.

On the doctrinal front, the French model is distinctive in the extent to which administrative law, both substantive and procedural, has been explicitly and comprehensively informed by the specific characteristics of the public sphere and the special prerogatives, duties, and rights that apply in the face of state action. One crucial example of this doctrinal apparatus is the concept of service public (Allison, 1996: 66-69; Brown and Bell, 1998: 129-34, 204, 230; Morand-Deviller, 2013: 455-98). Service public (public service) serves as a doctrinal device for allocating cases between the ordinary and the administrative court systems. In addition, administrative action involving a public service is subject to a special set of defenses and liabilities. The state is authorized to take whatever measures are necessary to ensure the continuity of the public service and to adapt the service to changing circumstances, rendering lawful administrative action which might otherwise be considered illegal or ultra vires. At the same time, the administration is required to treat all users of the service equally and neutrally. In the realm of government contracts, the administration is under a duty to compensate private parties for losses caused by any unilateral modification of contracts in the interest of the public service. In the common law tradition, the same outcomes might very well obtain in specific cases. However, the notions of policy discretion, expertise, the public interest, arbitrariness, and fairness that justify those outcomes have been developed separately, in different lines of cases involving different types of administrative litigation, and have not evolved under the single conceptual umbrella of service public.

Moving to the procedural principles that inform litigation in the French tradition, they too reflect the distinctiveness of public law (Fromont, 2006: 164-68). To obtain access to administrative courts, individuals are not required to allege a particularized harm since litigation against the state is conceived as vindicating an "objective" interest in a republican system of 
government faithful to the rule of law rather than "subjective" rights in property and liberty. In contrast to these quite generous rules on standing, remedies have traditionally been limited, based on the same theory of litigation as a means of achieving the proper operation of the state rather than individual justice. In the past, the Conseil d'Etat could either annul administrative acts or could award damages in tort litigation but did not have the tools to afford injunctive relief to individuals or to force recalcitrant administrative authorities to comply with its judgments. Over the past decades, the administrative courts have obtained a much wider array of remedial powers to address the gaps and injustices caused by this situation. Overall, however, French procedure stands in contrast with common law procedure, where individual standing and legal remedies are patterned on the principles of individual harm and redress characteristic of private law litigation.

Like the doctrinal and organizational composition of the two systems, the normative assessment of their relative merits has experienced a number of twists and turns over the decades. Dicey was emphatic that the common law stood on the side of liberty and the droit administratif on the side of authority. This position was fairly representative of nineteenthcentury politicians and scholars. For many continental reformers, the difference between the common law and droit administratif represented a choice between liberalism and absolutism. In the first part of the nineteenth century, most liberal thinkers in the German states advocated that legal control over administration be vested in the ordinary courts responsible for civil and criminal litigation (Stolleis, 2001: 215-18; Ledford, 2004: 208-11). Indeed, in the ultimately unsuccessful Constitution of the German Empire of 1849, the older system of purely internal and hierarchical review of administrative decisionmaking was rejected in favor of jurisdiction exercised by the courts: "Justice under the auspices of the administration shall cease; courts are to decide in all matters of violations of the law." (Article 182) In 1865, liberal currents influential at the founding of the unified Italian state succeeded in removing responsibility for administrative adjudication from the Italian Council of State and vesting the power to decide individual complaints in the ordinary courts (Mattarella, 2010: 1016). ${ }^{4}$ In the common law world, Dicey's

\footnotetext{
${ }^{4}$ In 1890, however, judicial powers were transferred back to the Council of State at least in part because of the ineffectiveness of the ordinary courts in curbing the growing powers of state administration (Mattarella, 2010).
} 
assessment remained influential well into the twentieth century (Allison, 1996: 23-27). For example, the American legal scholar Bernard Schwartz wrote in 1949:

The absence of public-law concepts, in the Continental sense, rather than being a defect of our jurisprudence is, thus, its great strength. It enables control over Executive action to be maintained through the same institutions that administer the normal law of the land, and on the same basic principles of justice. It prevents the State from placing its own officials in a privileged position by refusing to accept the assertion that different rules are applicable to their action. (151-52)

Even at the time that Dicey first pronounced the great divide, however, there were a number of thinkers who questioned his assessment of the two systems. As early as 1893 , the American scholar Frank Goodnow noted in his comparative study on administrative law in France, Germany, and the United States, "the great regard which the [French] administrative courts have for private rights" (231). The American political scientist James Garner prefaced his exposition of the French system in the Yale Law Journal by noting the "extremely liberal and progressive character" (1924: 597) of French administrative law and speculated that "[i]f an American may venture to criticize its [Conseil d'Etat's] jurisprudence he would say that it has been too progressive" (1924: 627). In his treatise Justice and Administrative Law (1928), the English public law scholar William Robson wrote enthusiastically of the French system, praised the emerging system of English administrative tribunals for their expertise and flexibility, and advocated entrusting most appeals to specialized administrative courts that were quite obviously in the mold of the droit administratif.

The debate on which of the two models is superior continues today. Some have come down on the side of the common law based on the absence of a jurisdictional divide between administrative and ordinary courts, thus avoiding expensive and lengthy litigation on the appropriate forum for hearing claims against state actors (see generally Brown and Bell, 1998: 297-99). Harking back to the nineteenth-century liberty-authority dichotomy, the European Court of Human Rights has recently questioned whether the institution of a Council of State 
satisfies the requirement of independence that is part of the right to a fair trial (Article 6 of the European Convention on Human Rights). In this regard, the Court has criticized the practice of mixing regulatory and adjudicatory functions in the Council of State. ${ }^{5}$ It has also sought to reduce the institutional presence of the Commissaire du gouvernement, a member of the Council of State who does not actually sit in judgment but is tasked with advising the judges on the correct outcome of the case and whose role is conceived as informing the judges on the objective state of the law (Bell, 2010).

Others, by contrast, have highlighted the virtues of the French model. In the 1960s and 1970s, the Scottish scholar J.D. Mitchell lamented the absence in the common law of a coherent system of public law similar to what had developed in France and went so far as to state that the great "tragedy" of the common law was that there was no general concept of "administrative morality" (1965: 113). His criticism was based on a number of absurdities that had been generated in the piecemeal and evolutionary process of seeking to extend the common law to the administrative state. In the United States, the legal scholar and now Supreme Court Justice Stephen Breyer has suggested that a central executive body similar to the Conseil d'Etat might be the answer to improving the quality of federal regulation (1995: 70-72). In Breaking the Vicious Circle, Breyer wrote an early account of the failure of federal regulation to adequately prioritize in policy areas such as public health and consumer well-being and to develop coherent and cost-effective strategies to tackle risk. His proposed solution, a centralized group of career bureaucrats with the power to oversee the regulatory initiatives of federal agencies, incorporated many of the key attributes of the Conseil d'Etat. Like the Conseil d'Etat, the executive body would have the power to review and annul draft regulations, would be staffed by officials recruited through a rigorous selection system with technical expertise in specific areas of regulation, and would be built on a career model in which officials regularly rotated in and out of regulatory agencies. These institutional features would all guarantee the prestige and technical competence of the regulatory oversight body. Although Breyer mostly drew inspiration from the regulatory function of the Conseil d'Etat, he also suggested that his proposed oversight body

\footnotetext{
${ }^{5}$ Procola v. Luxembourg, 326 Eur. Ct. H.R. (ser. A) (1995).
} 
would be well suited to adjudicate legal disputes over regulation and that it might eventually supplant or even entirely replace the jurisdiction of the federal courts (Breyer, 1995: 72).

This is not the place to weigh in on a classic debate in the comparative law literature which, as demonstrated above, has a long history and shows no sign of abating. It is clear, however, that the two models have important consequences for cultures of judicial review in France, the United Kingdom, and the many jurisdictions across the world that have been influenced by the two legal traditions. They also have ramifications specifically for regulatory governance. One of the most significant transformations of the administrative state that has occurred with the rise of regulatory governance is the shift from direct state intervention in important sectors of the economy to the reliance on rules to govern a competitive private market and to achieve some of the same policy outcomes as direct management. These rules, unlike most of the instruments used in state ownership and industrial policy, are formal and are subject to legal challenges from the market and civil society actors governed by the rules. Such challenges can be expected to operate somewhat differently in the common law and the droit administratif traditions. One difference relates to access to justice. The procedural rules of the French tradition, aimed at safeguarding the rule of law and the republican form of government, should make it relatively easy and quick to obtain judicial review of administrative rules. By contrast, in the common law model, the necessity of satisfying standing requirements analogous to those applicable in private litigation should make judicial review less widely available and less immediate.

In addition, the organizational attributes of the two systems of adjudication are likely to influence how rules are scrutinized. As will be recalled, the regulatory and adjudicatory functions are institutionally mixed in the French system. The members of the Conseil d'Etat have significant, direct experience in the upper echelons of the administration. When they serve on the Conseil d'Etat, they are called upon, at different points in their career, both to advise on proposed laws and regulations, and to decide on challenges to regulations after they come into effect. Although different sections are responsible for the regulatory and adjudicatory functions, the voluminous file generated when the rule is proposed is generally also consulted if that same rule is subsequently challenged (Latour, 2010). This combination of functions does not mean, as 
Dicey would have it, that the Conseil d'Etat is necessarily more deferential towards state authority; indeed it might very well be less deferential because it has professional knowledge of regulation and administrative agencies. It does suggest, however, that arguments on the technical and legal substance that are not squarely raised at the time of the rulemaking, both within the government and in the context of regulatory review by the Conseil d'Etat, are less likely to be taken seriously on judicial review. By contrast, in the common law tradition, where the judges that decide administrative cases are generally outsiders to the rulemaking process, arguments that were peripheral in the rulemaking process may find greater acceptance at the time of judicial review.

\section{ADVERSARIAL VERSUS DISCRETIONARY POLICYMAKING}

In the early 1990s, scholarly attention turned to a second major split in systems of judicial review of government policymaking, this time not between England and France but between the United States and Europe (and for some purposes, Japan). Reflecting on the experience in the 1960s and 1970s with law and politics in advanced democracies, Robert Kagan developed the theory of “adversarial legalism" (1991, 1994, 1997, 2001). To make his comparative argument, Kagan drew on a number of cross-national studies in the law-and-society tradition that examined the operation of the administrative state on the ground in Western Europe, Japan, and the United States. He argued that policymaking and dispute resolution in the United States in virtually every area of social and economic life was more lawyer-driven and court-dominated than in other democracies, which instead relied more heavily on discretionary policymaking by bureaucrats and politicians and hierarchical dispute resolution by judges. ${ }^{6}$ His theory applies across the board to most areas of law but has special relevance for the law of the regulatory process. Kagan demonstrated that American legislation is more vulnerable to legal challenges, involving aggressive lawyering, novel theories of constitutional law, and activist courts. The American system also relies more heavily on litigants and courts for regulatory implementation and

\footnotetext{
${ }^{6}$ The difference in "regulatory styles" was also identified by David Vogel in an early monograph on environmental policy (1986).
} 
enforcement than other jurisdictions, which give bureaucracies greater powers and have relatively restrictive rules on class actions and other procedural devices that can facilitate litigant access to courts (see also Hensler, this volume). Rulemaking in American bureaucracies is more proceduralized and lawyer-driven than in most other countries (see also Wagner, this volume; Smismans, this volume). Enforcement by American administrative agencies is more legalistic and punitive. And, most relevant for this chapter, the regulatory policies enacted by the political branches and implemented by bureaucracies are more likely to be challenged in the courts and defeated under theories of administrative and constitutional law than in other advanced democracies.

Kagan's explanation for the emergence of adversarial legalism rested both on historically deep-rooted structural and ideological differences, as well as more recent events associated with the post-material turn taken in most western democracies in the 1960s and 1970s. To simplify a highly nuanced account, Kagan argued that adversarial legalism was brought on by a burst in citizen demand for public interest regulation combined with a long-standing American culture of distrust in the state and an institutional framework of small and divided government. In contrast with Europe, the ambitious regulatory programs of the 1960s and 1970s operated in a context of legal and institutional fragmentation. When the new programs were designed by Congress, implementation was not delegated exclusively to a large state bureaucracy, as was the case in many other democracies, but to a combination of federal administrative agencies, state and local governments, and private attorneys general with the power to enforce regulation directly, in court. To compensate for the policy slippage created by this fragmented arrangement, Congress wrote laws that were highly detailed on both the substance and the procedure and that would enable private litigants to sue the different government bodies in court to enforce their statutory mandates, namely, to obtain judicial review. Thus the legal framework for adversarial legalism was put into place. As the conceptual label indicates, Kagan's normative assessment was fairly negative. He suggested that the more informal, consensual, and administratively driven system at work in Europe was just as effective or more so at delivering policy goods and guaranteeing social welfare, but without the cost and uncertainty generated by the many layers of lawyers, courts, and contestation characteristic of the American system. 
At roughly the same time as Kagan wrote, a number of political scientists working in the rational-choice tradition came to focus on the administrative law component of adversarial legalism (McCubbins et al., 1987, 1989; Epstein and O'Halloran, 1994, 1999; Huber and Shipan, 2002). This line of inquiry elaborates on why judicial review of agency policymaking can be so demanding in the American system and has been influential in both political science and the law. The premise of this rational-choice scholarship is that the relationship between legislatures and administration can be conceived as a principal-agent relationship in which the legislature (principal) has incentives to delegate the power of policy implementation to administration (agent) but administration, in turn, has incentives to defect from the policy preferences of the legislature. Legislators, therefore, build into the law a number of devices to control wayward bureaucrats. The innovation of the leading proponents of this approach, Matthew McCubbins, Roger Noll, and Barry Weingast (McNollgast), was to conceptualize control tools broadly to include not only statutory commands and Congressional oversight but also administrative procedure and judicial review. McNollgast argued that, notwithstanding the outcome-neutral appearance of many administrative procedures, they were designed to entrench legislative bargains and to ensure that the interests that had prevailed in the legislative process would do so also in the administrative process. In their framework, procedural requirements related to transparency, participation, and reason-giving within the bureaucracy, and the right to enforce such requirements through judicial review, allowed the interest groups behind the enacting coalition to monitor and influence, either directly or through their legislators, administrative outcomes. McNollgast captured a wide array of procedural requirements, backed by judicial review, some of which were relatively new, for instance specific reporting requirements written into environmental legislation, and some of which were more general and of older vintage, such as the rulemaking provisions of the Administrative Procedure Act. The vast majority of these requirements, conceived in rational-choice theory as principal-agent control instruments, were also among those blamed by Kagan for adversarial legalism.

Most of the rational-choice scholarship on regulatory design is focused specifically on the United States and the relationship between federal administrative agencies and Congress. A few scholars, however, have engaged in comparative analysis to highlight and explain the relative 
absence elsewhere of formal procedural safeguards in the regulatory process, together with a reduced role for courts and judicial review (Moe and Caldwell, 1994; Epstein and O'Halloran, 1999: 242-44; Thies, 2001; Strøm 2003; Jensen and McGrath, 2011; Rose-Ackerman et al., 2015; Rose-Ackerman et al., this volume). They focus on the different strategic incentives that exist in the institutional context of American presidentialism-an important aspect of fragmented American government-and parliamentarism, the form of government prevalent in Europe and much of the rest of the world. In line with principal-agent theory, procedural constraints on administrative action are conceptualized as a device for locking in political deals when policy implementation is delegated to administrative actors. Although the accounts vary, they converge on a couple of characteristics of parliamentary government that make procedural rights and judicial review a less likely strategy of political control for legislatures. First, when the same majority party or coalition of parties controls both the legislature and the government, the likelihood of defection is lower: administrative agencies have fewer opportunities and face less pressure to defect from the legislative bargain since they report only to one political principal and not to the multiple principals of Congress and the President (especially problematic in periods of divided government). Secondly, formalization is a costly mechanism for entrenching political deals because it reduces administrative flexibility, imposes cumbersome and timeconsuming procedures, and introduces third-party monitors in the form of interest groups and the courts which themselves may be a source of principal-agent slack. Thirdly, there exist alternative, less costly forms of control in parliamentary systems, such as the political appointment of ministers and junior ministers who can monitor the work of bureaucracies and can, in the case of a multiparty coalition, ensure that the coalition agreement rather than any one party in the coalition prevails in the administrative policymaking process. Fourthly, because of the concentration of legislative power in the governing coalition or majority party, administrative procedure operates as a relatively ineffective and therefore unlikely instrument of control in parliamentary systems: even if a particular legislature did enact administrative procedure, a subsequent legislature would be likely to quickly undo it, incentivized by the limited benefits and extensive costs of procedure described above. 
Among those who have considered the ramifications of this institutional difference for comparative public law, the work of Susan Rose-Ackerman is among the most significant. In an earlier study on German and American environmental policy (1995: 125-33) and recent research on policymaking procedure in a number of legal systems (Rose-Ackerman et al., 2015; RoseAckerman et al., this volume), she has argued in favor of American rulemaking procedure and judicial review. The normative argument closely dovetails the positive, rational-choice analysis: in her theoretical account, transparency, participation, and reason-giving in the administrative process, backed by judicial review, enable both legislators and citizens to oversee administrative agencies and therefore render executive policymaking democratically accountable. At the same time, Rose-Ackerman argues that procedure and judicial oversight ensure that bureaucrats will make decisions in a technically competent fashion that comports with means-ends rationality. Returning full circle to the more general differences traced by Robert Kagan between American adversarial legalism and the European administrative state, it should be clear that RoseAckerman departs significantly from his assessment of the two systems. In her analysis, the costs associated with procedure and judicial review are outweighed by the benefits to democratic accountability and policymaking competence.

To summarize, adversarial legalism and the institutional structure of presidentialism have significant implications for the judicial review component of government policymaking in the United States. As compared with other established democracies, policymaking within administrative agencies is more formal, proceduralized, and adversarial. American bureaucrats are more likely to be sued in court, both for having breached the onerous procedural requirements and for having failed to satisfy the substantive standards of administrative rationality. The difference applies precisely to the activities specifically associated with the regulatory function-designing generally applicable rules that regulate liberalized markets. Other administrative activities such as the mass adjudication of individual claims in the context of welfare programs tend to be proceduralized and amenable to judicial review everywhere, driven by the liberal commitment to fair procedure in individualized determinations. With the rising prominence of regulation, making it an important form of governance not only in the United States but also in the European Union and other parts of the world, some have suggested that 
rulemaking too will become adversarial everywhere (Kelemen, 2011; Kelemen, this volume). Whether this is indeed the case is an open question that will continue to be the subject of debate for some time to come (Bignami and Kelemen, forthcoming).

\section{RIGHTS VERSUS DEMOCRACY}

In recent years, a third divide between systems of judicial review of government policymaking has become increasingly apparent. This is the contrast between judicial review based on theories of fundamental economic and social rights, which is prevalent in European legal systems and, a growing body of evidence suggests, jurisdictions in other parts of the globe; and judicial review conceived as a handmaiden of the democratic process, which dominates in the United States. As I have begun to elaborate elsewhere, outside of policing administrative actors for fidelity to statutory mandates, American and European courts take fundamentally different approaches to the judicial review of public policymaking (Bignami, 2011: 898-902; 2012: 148-60). While European courts safeguard a wide range of liberties from the burdensome action of policymakers, American courts seek to advance a particular vision of democracy in the administrative process. In the rest of this section, I elaborate on the two theories of judicial review, suggest an explanation for the different jurisprudential trajectories, and explore some of the possible implications of the difference.

To begin with Europe, the most prominent example of judicial review driven by fundamental rights is the principle of proportionality. It is associated with the same political philosophy of liberalism discussed earlier in connection with the historical development of administrative litigation. Proportionality's origins are generally traced to nineteenth-century Prussia and the gradual shift from absolutism to the rule of law or, in the language of the time, the shift from "der Polizeistaat" to the "Rechtstaat" (Barak, 2012: 175). In Germany, as in much of the rest of continental Europe, one of the defining elements of liberalism and the rule of law was the recognition of a private sphere of liberty and property independent of the state (Stolleis, 2001). To safeguard that private sphere, it was critical that all government interferences with property and liberty be authorized by law and that individuals be able to go to court if state 
officials exceeded the boundaries of that law. The rule of law, however, was also tied to the identification of a set of rights guaranteed by natural law and judicial control designed to protect those rights. This was especially apparent in the shifting terrain of the police power. Although local authorities still operated under vague statutory provisions directing them to protect public health and security, a fairly elaborate conceptual apparatus was developed in the law to limit their powers and their intrusion upon liberty and property, including the principle of proportionality.

Proportionality was used in Prussian courts and legal scholarship to curtail the type of action, if any, that could be used by local authorities to protect public health and security. Today's legal scholarship generally defines proportionality as comprised of three elements: whether the government action is capable of achieving the stated end (suitability); whether the government action is necessary to achieve the stated end (necessity); and whether on balance the benefits from the government action outweigh the burdens on individual rights (balancing or proportionality stricto sensu) (Grimm, 2007). The first two elements in particular (suitability and necessity) were apparent in Prussian law. As the leading administrative law scholar of the time, Otto Mayer, explained:

The basis of the police power in natural law requires that the [protection of the good order of the public thing] be in proportion to the disturbance; this defines the extent of the action of the police. It should not be presumed that the law, through general authorizations by virtue of which the authority of the police operates, wished to permit such protection to exceed this natural limit. (1904: 29)

Thus, for instance, in a case decided in 1880, the Prussian Supreme Administrative Law Court found against the police because they had banned all women likely to be prostitutes from entering the home of a suspected pimp rather than resorting to the less intrusive surveillance measures available to them (1904: 32). Although the third element of proportionality (balancing) is harder to discern, there is evidence of the concept in the legal scholarship of the time. Again referring to Otto Mayer, he argued that when public authorities exercised the police power they 
were bound to demonstrate that the beneficial effects of public action outweighed the burden on private life (1904: 20-21n. 2). At issue in the particular case under consideration was a Berlin ordinance forbidding the use of stove-pipe keys in homes, which according to Mayer constituted an especially burdensome interference with the protected sphere of "private life."

After World War II and the adoption of the German Basic Law, proportionality rapidly became an overarching principle of both administrative law and constitutional law. In the 1950s, the concept was elaborated by administrative law scholars to include the three elements of suitability, necessity, and balancing, and came to be applied to all forms of administrative action (von Krauss, 1955; Lerche, 1961). Soon thereafter, the concept migrated to constitutional law with the judgment of the Federal Constitutional Court in the Pharmacy Case. ${ }^{7}$ This famous case involved a challenge to a Bavarian statute that set down criteria for granting permits to pharmacies, including economic viability and the potential harm to competitors. A pharmacy that was denied a permit sued based on the constitutionally guaranteed right to choose and exercise a profession. The Court, in holding for the pharmacy, assessed the liberty claim based on the proportionality principle and in doing so provided the first clear endorsement of the principle in constitutional law. In the judgments that immediately followed, it became clear that proportionality would apply in any case involving rights and liberties. Since then, it has become a cornerstone of constitutional law and has become one of the leading German legal exports to the rest of the world (Barak, 2012: 182).

Given how prominent proportionality has become in constitutional law, it is easy to focus on cases involving political and civil rights such as freedom of expression and race discrimination and to lose sight of how the principle originated in the classic economic rights implicated by the administrative state. Today it is still used in the economic domain. A couple of examples will illustrate the point. The first is the German case that led to the adoption of proportionality in European Union (EU) law. In Internationale Handelsgesellschaft, a German company failed to export the quantities of maize stipulated in an export license it had obtained pursuant to an EU

7 Bundesverfassungsgericht [BVerfG] [Federal Constitutional Court] June 11, 1958, 7 Entscheidungen des Bundesverfassungsgerichts [BVerfGE] 377. 
Council regulation and, as a result, pursuant to the terms of the regulation, it forfeited the entire amount of the deposit it had provided at the time it had obtained the license. ${ }^{8}$ The company challenged the regulation before a German administrative court based on the rights of freedom of action and economic freedom guaranteed under Articles 2(1) and 14 of the German Basic Law. The German court referred the proportionality question to the Court of Justice, which recognized for the first time that such liberties, along with the related proportionality principle, were part of EU law. The Court of Justice then conducted the proportionality inquiry: it found that forfeiture of the deposit was both suitable and necessary to the end of ensuring that the Commission was properly informed of the overall volume of exports and imports, essential to regulating the market in agricultural commodities. Turning to the balancing component of the test, namely whether the burden on the individual right was disproportionate to the public benefits from the policy, the Court found that since the amount of the deposit was minimal and there was a force majeure exception to the forfeiture, the EU regulation satisfied proportionality stricto sensu.

Returning to the German Federal Constitutional Court, it has routinely acted to protect the right of occupational freedom and the related proportionality principle at issue in the historic Pharmacy Case. In a challenge brought by a candy manufacturer to a federal regulation banning the sale of cocoa-like products because of the risk to consumers of confusing such sweets with real chocolate, the Court found that the necessity prong had been violated because of the availability of a less-restrictive measure-a labelling requirement-to prevent consumer confusion. ${ }^{9}$ In another case, occupational freedom lost out to animal welfare. ${ }^{10}$ The Court found that a farming regulation prescribing the minimum dimension of chicken coops was too favorable to farmer rights and did not adequately guarantee the animal welfare interests protected under the enabling statute. More recently, based on the same right of occupational freedom, the Court struck down a law banning smoking in public restaurants because of the failure of the statutory scheme to consistently promote the purported aim of protecting against smoke. ${ }^{11}$

\footnotetext{
${ }^{8}$ Case 11/70, Internationale Handelsgesellschaft v. Einfuhr, 1970 E.C.R. 1125.

${ }^{9}$ BVerfG, Jan. 16, 1980, 53 BVerfGE 135.

${ }^{10}$ BVerfG, Apr. 13, 1999, 101 BVerfGE 1.

${ }^{11}$ BVerfG, June 11, 2008, 121 BVerfGE 317.
} 
As has already been suggested, proportionality is not confined to German law, but has become central to European law, in both national jurisdictions (Fromont, 2006: 255-61; Barak, 2012: 186-87; Rose-Ackerman et al., this volume) and the supranational European Union (Tridimas, 2006: 136-241) and European Court of Human Rights (Letsas, 2006: 711). It has also spread to legal systems outside of Europe, including Israel, Canada, South Africa, India, South Korea, and Taiwan (Barak, 2012: 188-204; Huang and Law, this volume). Important for the purposes of this chapter, it protects liberty from both legislative and administrative action, and it extends to all types of rights, although with different levels of intensity, including civil, political, and economic rights and even, in some cases, positive social and economic rights.

Another important example of how fundamental rights are used in European law to curb government policymaking is the principle of equality. While German law is at the origin of proportionality, the genealogy of equality is often traced to French law. In the jurisprudence of the Conseil d'Etat on general principles of law (principes généraux du droit)-higher-law principles rooted in political theories of liberalism and republicanism and enforced against administration and the political executive-equality is one of the oldest and most fundamental (Long et al., 2013: 418). The principle of equality is loosely linked to the Declaration of the Rights of Man and of the Citizen of 1789, and was first recognized by the Conseil d'Etat in 1913 in the Roubeau case. ${ }^{12}$ It applies to both policymaking and individual decisionmaking and has evolved into a series of specific principles applicable to certain types of government activity: equality in the operation of public services, ${ }^{13}$ equality in taxation, ${ }^{14}$ equality in bearing public burdens (charges publiques) ${ }^{15}$ equal access to the civil service, ${ }^{16}$ equality between members of the civil service, ${ }^{17}$ sex equality, ${ }^{18}$ equality between nationals and non-nationals in the domain of fundamental rights, ${ }^{19}$ equality between users of public services or state-owned property

\footnotetext{
${ }^{12}$ CE May 9, 1913, Rec. Lebon 521.

${ }^{13}$ CE Sect., Mar. 9, 1951, Rec. Lebon 151.

${ }^{14}$ CE Sect., Feb. 4, 1944, Rec. Lebon 45.

${ }^{15}$ CE Nov. 30, 1923, Rec. Lebon 789.

${ }^{16}$ CE Ass., May 28, 1954, Rec. Lebon 308.

${ }^{17}$ CE Sect., Oct. 26, 1979, Rec. Lebon 396.

${ }^{18}$ CE Ass., July 3, 1936, Rec. Lebon 721.

${ }^{19}$ CE Ass., Dec. 8, 1978, Rec. Lebon 493.
} 
(domaine public), ${ }^{20}$ and equal treatment under economic regulation. ${ }^{21}$ The principle is generally formulated as the duty to treat equal situations equally and different situations differently and requires that any difference in treatment be justified in light of the objectives of the enabling law (Fromont, 2006: 254).

A couple of examples will illustrate the reach of the equality principle and how deeply it cuts into the operation of the administrative state, including the regulatory function. In what is generally recognized as the foundational case for equality in the area of public services, the Conseil d'Etat annulled a decision of Radiodiffusion français (a public broadcasting service) in which it refused to broadcast concerts organized by the Société des Concerts du Conservatoire. ${ }^{22}$ The Conseil d'Etat found that as the provider of a public service the broadcaster was bound by the equality principle, that it had violated that principle by singling out Société des Concerts du Conservatoire and refusing to broadcast its concerts, and that it was consequently liable in damages. In 1985, a Paris police regulation restricting permits for sidewalk vendors to war victims, persons with family, and needy persons was found to impermissibly discriminate against other types of applicants. ${ }^{23}$ The Conseil found that the "general interest, which is linked to the social protection of persons so defined was not sufficiently important to entirely exclude all other applicants." In 2011, the Conseil annulled a provision of the highway code delegating the task of automobile safety inspections to auto repair shops that were members of a national organization on the grounds that it violated the principle of equality as between affiliated and independent auto repair shops. ${ }^{24}$ Even more recently, the Conseil annulled a social security decree increasing pension benefits for mineworkers which only applied to workers with a lengthy employment history on the grounds that the ministry had failed to justify the difference between the two

${ }^{20}$ CE Sect., Nov. 2, 1956, Rec. Lebon 403.

${ }^{21}$ CE Oct. 26, 1949, Rec. Lebon 433.

${ }^{22}$ CE Sect., Mar. 9, 1951, Rec. Lebon 151.

${ }^{23}$ CE Sect., Dec. 18, 1985, Rec. Lebon 380. For a similar set of facts and legal arguments in a case decided by the South Korean Constitutional Court, see Huang and Law (this volume).

${ }^{24}$ Société Auto Bilan France, 6/1 SSR, 342498, Oct. 21, 2011, reported in Jurisprudence des formations contentieuses du Conseil d'Etat, Oct. 2011, at 17. 
classes of mineworkers. ${ }^{25}$ Of course, there are numerous instances in which the Conseil has rejected equality claims, indeed probably more numerous than those in which it has upheld them. For instance, in a case dating to 1983, the Conseil heard a challenge to a government decree declaring a certain territory to be a natural reserve and regulating the use of the reserve. ${ }^{26}$ One of the complaints was that the government had impermissibly singled out certain areas of the reserve for camping and bivouacing, to the exclusion of the rest, but the Conseil found that difference in treatment was justified by the objective of nature protection.

As with proportionality, the equality principle made its way early on to the European Court of Justice. It first appeared in the 1950s in cases challenging civil service decisions of the EU institutions ${ }^{27}$ as well as High Authority decisions involving the differential treatment of coal and steel producers and users. ${ }^{28}$ Somewhat later, the principle emerged in challenges to regulatory decisions in the common agricultural policy area which discriminated between different types of producers. ${ }^{29}$ It is also common to the administrative law of the member states, in particular the judicial review of administrative rules (Fromont, 2006: 253, 293), and to national constitutional law (Baer, 2012; Kommers and Miller, 2012: 419-40), including French constitutional law since the expansion of the Constitutional Council's powers in the 1980s (Stone, 1992). Although there has been less attention to equality than to proportionality in the comparative literature, it appears to operate as a cross-cutting principle in a number of jurisdictions outside of Europe too (Huang and Law, this volume). In addition, similar to proportionality and important for understanding judicial review in the context of the regulatory state, equality is a principle applicable in both the administrative and legislative domains, and generally protects against all forms of discrimination, including social and economic classifications.

\footnotetext{
${ }^{25}$ Syndicat national CFDT des mineurs et assimilés et du personnel du régime minier et autres, $1 / 6$ SSR, 353703, 353707, 353781, Nov. 27, 2013, reported in Jurisprudence des formations contentieuses du Conseil d'Etat, Nov. 2013, at 16.

${ }^{26}$ CE Ass., May 19, 1983, Rec. Lebon 205.

${ }^{27}$ See, e.g., Case 1/55, Kergall v. Common Assembly, 1955 E.C.R. 151, 169.

${ }^{28}$ See, e.g., Case 8/57, Hauts Fourneaux et Aciéries Belges v. High Authority of the European Coal and Steel Community, 1958 E.C.R. 245.

${ }^{29}$ See, e.g., Case 114/76, Bela-Müle Josef Bergmann KG v. Grows-Farm GmbH, 1977 E.C.R. 1211.
} 
There are a number of other doctrines that are also designed to protect liberty in the context of the contemporary administrative state. These are generally concerned with positive rights such as government benefits and have been recognized in the primary law of constitutions and in the court-generated principles of non-retroactivity, legal certainty, and legitimate expectations (Kommers and Miller, 2012: 622-23; Bignami and Spivack, 2014). While the constitutional law generally begins from the premise that individuals are entitled to a certain minimum level of welfare from the state, the judge-made principles are designed to restrict changes to government programs once they have been put into place by legislative and administrative actors.

In the American system, by contrast, individual rights rarely form the basis for judicial review of the market-regulating and welfare-distributing functions of the contemporary administrative state. This is a product of the rigid hierarchy of fundamental rights which is distinctive to the American system and which has been amply documented in scholarship on comparative constitutional law (Mathews and Stone Sweet, 2011; Barak, 2012: 509-27). Economic rights and classifications are part of the lowest tier of the hierarchy, which is afforded only minimal, so-called "rational basis" judicial review; most commentators agree that, once a case is slotted into the "rational basis" category, the outcome, in favor of the state and against individual rights, is a foregone conclusion (Sunstein, 1985). As Aharon Barak explains, in contrast with proportionality and equality, which are applied in every case to balance between the injury to the fundamental right and the general interest that motivates state action, the American approach seeks to balance in advance, through the constitutional hierarchy of rights (2012: 512). Rights at the top of the hierarchy, such as the right to speech, require a very good justification from the state before the interference will be considered permissible. Rights at the bottom of the hierarchy, including economic rights, require virtually no justification at all to warrant state interference. Therefore, cases involving rights such as the right to exercise a profession or conduct a trade, which have a chance of success under the principles of proportionality and equality, automatically fail under rational basis review.

The absence of fundamental rights from judicial review of the American administrative state is also a function of the tendency of the Supreme Court, in contrast with other constitutional 
courts, to define the scope of rights narrowly and to refrain from creatively interpreting constitutional text to recognize new rights (Currie, 1989). This has had an impact especially in the domain of the welfare state: the Supreme Court has not recognized any positive social and economic rights under the Constitution and there are few judge-made constraints on drastic shifts in entitlement programs, either at the legislative or the administrative levels (Bignami and Spivack, 2014). In other words, the hardship created by the revocation of government benefits and other types of advantageous treatment is not tempered, as in certain European jurisdictions, by positive constitutional rights and judicial doctrines such as legitimate expectations and legal certainty.

As the literature on adversarial legalism and delegation demonstrates, American courts do intervene in government policymaking. They do so, however, based on theories related to the preservation of the democratic process, or what I call the "ballot-box democracy" paradigm of public law. In reviewing legislative action, American courts police for fidelity to federalism and the other structural guarantees of the Constitution; in reviewing administrative policymaking, courts engage in what one leading administrative law scholar has labelled "proceduralized rationality review" (Mashaw, 2012: 289). In the interest of space, this section will focus on the latter form of review-judicial oversight of administrative actors when they engage in policymaking. Proceduralized rationality review encompasses a number of doctrinal grounds of review, both the procedural requirements analyzed in the previous section and in other chapters in this volume (Wagner; Rose-Ackerman) and the substantive standard of "arbitrary and capricious" review. Arbitrary and capricious review, also known as "hard-look review," was originally designed to capture instances of irrational agency action but evolved, in the early 1970s, into a highly demanding test (Breyer et al., 2002: 416; Schiller, this volume). ${ }^{30}$ It was layered over the long-standing appellate model of American judicial review (Merrill, 2011) in which the factual record, policy analysis, and legal basis for the decision were to be developed primarily by the administrative agency, conceived as analogous to a trial court. The result is that

\footnotetext{
${ }^{30}$ As a matter of formal legal doctrine, there are a number of other tests that can apply in the context of judicial review of the substance of agency policy decisions, but the arbitrary and capricious standard is by far the most common, and indeed some argue that there is very little difference in how the different tests operate in practice (Zaring, 2010).
} 
administrative agencies must demonstrate before the courts that, at the time the policy choice was made, they considered and assessed all of the available legal and policy options and came to a reasoned conclusion as to which policy would best accomplish the underlying goals of the regulatory scheme. ${ }^{31}$

The rationale for proceduralized rationality review was tied to two distinct but related elements of the democratic process. In the 1960s and 1970s, a burgeoning literature had brought attention to what was believed to be the widespread "capture" of administrative agencies by regulated industries (Olson, 1965; Stigler, 1971, 1974). The response was twofold. First, by enforcing a demanding standard of rationality, courts would ensure that administrative agencies promoted the goals of the legislature rather than the special interests of the regulated community. As Judge Leventhal said in his seminal article on hard-look review, the objective was to ensure that the agency "has exercised a reasoned discretion with reasons that do not deviate from or ignore the ascertainable legislative intent. ... [The entire process] is conducted with an awareness that agencies and courts together constitute a 'partnership in furtherance of the public interest'" (1974: 511). Secondly, by ensuring a fair and representative agency process that largely mimicked the pluralist system of interest group competition in the legislature, public interest groups such as consumers and environmental advocates would be heard from beginning to end of the policymaking cycle. Surveying and synthesizing a wide range of developments in the field of administrative law, Richard Stewart dubbed the emerging practice of judicial review the "interest representation model": the use of judicial review "to ensure more adequate representation for all interests affected by agency decisions" (1975: 1669).

Before exploring the implication of these two models of judicial review specifically for regulatory governance, it bears asking why they emerged in the first place. The comparative

\footnotetext{
${ }^{31}$ European courts also require that administrative agencies give reasons for their policy choices. Such reasons, however, can be advanced in the litigation and are not required to be developed in the context of the agency rulemaking in response to the regulated parties (Allison, 1996: 207-34; Singh, 2001: 223-43). Therefore rationality review is not as "proceduralized" (and as drawn out) as in the American case. Moreover, the notion of administrative discretion, understood as a decisionmaking sphere legitimately left to bureaucracies and illegitimately usurped by the inference of courts, is more robust in Germany and other European legal systems (Maurer, 2009: 133-64). As a result, the reason-giving generally required in administrative law review-as opposed to review on constitutional liberty grounds-is a relatively cursory explanation of how the policy choices made by the administrative authority are consistent with the overall legal framework of the government program.
} 
analysis reveals two quite different theories of public law: one that explicitly calls upon fundamental rights to theorize the relationship between courts and the administrative state and the other that is rooted in a duty to protect a specific understanding of democracy in the policymaking activities of bureaucracy. On the American side, the explanation rests in the experience of courts in the early days of judicial review and democratic government and the impact of that experience on the subsequent development of legal discourse and judicial behavior. In what has become a standard narrative in American constitutional history, in the first decades of the twentieth century, the Supreme Court came into direct confrontation with popular politics and elected legislatures. At this time, it repeatedly struck Progressive and New Deal legislation based on liberty and property rights and a narrow vision of the police power. In Lochner (1905), the most famous of these cases, the Court struck a New York law regulating the working hours of bakers as a violation of the Due Process Clause and the so-called "substantive" guarantee of liberty under the Due Process Clause to enter freely into contracts of employment. ${ }^{32}$ The period was marked by clashes within the legal establishment between legal realists and adherents to the "classical" school of thought (Horwitz, 1992) and by contrasting views, both inside and the outside the Court, on the correctness of the Lochner line of cases. It was also a period of intense conflict between the President and the Court. In what has become a notorious episode in American constitutional history, Roosevelt sought to "pack" the Court with six additional Justices who presumably would have ensured the constitutionality of the New Deal agenda (Ackerman, 1998: 312-37).

While the Court-packing bill was ultimately defeated in the Senate, the Court shortly thereafter reversed course and began upholding the ambitious regulatory programs of the New Deal. In doing so, it abandoned several different doctrinal threads, including the substantive due process jurisprudence of the Lochner era. ${ }^{33}$ At the same time, the Court articulated a new philosophy of judicial review. In Carolene Products, the Court easily dismissed a substantive due process challenge to a federal statute prohibiting the sale of milk that had been compounded

\footnotetext{
32 Lochner v. New York, 198 U.S. 45 (1905).

${ }^{33}$ The seminal case is West Coast Hotel Co. v. Parrish, 300 U.S. 379 (1937), in which the Court decided that the minimum wage set down in a Washington state statute was constitutional.
} 
with non-milk fats. ${ }^{34}$ (In fact, the legislation at issue in the case recalls the German chocolate regulation mentioned earlier which, in contrast with the outcome in Carolene Products, was struck by the German Constitutional Court based on the right of occupational freedom and the proportionality principle.) The Supreme Court declared that, in cases involving "regulatory legislation affecting ordinary commercial transactions," it would generally assume a rational basis that justified the use of the police power unless proven otherwise "in the light of the facts made known or generally assumed." ${ }^{35}$ Thus the economic liberties that we have seen are routinely litigated in European legal systems were dismissed as outside the power of courts with the exception of egregious violations. By contrast, the Court indicated that it would engage in more searching scrutiny in three categories of constitutional cases: (1) those which involved rights specifically protected by the Bill of Rights; (2) restrictions on "those political processes which can ordinarily be expected to bring about repeal of undesirable legislation" and associated rights such as the right to vote and the right to speech; and (3) legislation curbing the rights of "discrete and insular minorities ... which tends seriously to curtail the operation of those political processes ordinarily to be relied upon to protect minorities." ${ }^{36}$ These types of claims were identified as legitimate for judicial review because they were specifically identified in the text of the Constitution or because they served to protect the democratic process.

This set of events, together with the dominant interpretation in the legal establishment, has profoundly marked contemporary judicial review. Although the historiography has undergone significant revision over the past 20 years (Gillman, 1993; Mayer, 2009), the prevailing view at the time and to some extent still today is that the Lochner-era cases were driven not by principled legal positions but by the conservative ideological preferences of the justices. In doing so, the Supreme Court had illegitimately interfered with democracy and the will of the majority as expressed by the directly elected bodies of government. It had imposed the politics of the nine members of the Court on the nation. As a contemporary scholar, writing in 1942, put it:

\footnotetext{
${ }^{34}$ U.S. v. Carolene Products, 304 U.S. 144 (1938).

${ }^{35}$ Id. at 152.

${ }^{36}$ Id. at $152 \mathrm{n} 4$.
} 
A considerable number of the decisions under the expanded version of due process ... undoubtedly are expressive of an extreme laissez-faire philosophy. . . . [T] he economic and social individualism of the seventies [1870s] and eighties [1880s] was created by that generation rather than inherited from the founders. It was the creed of a minority which, like the Federalists of two generations before, was fast losing out at the polls. (Wright, 1942: 255)

The new philosophy of judicial review laid down in Carolene Products both repudiated a general mandate to safeguard liberty and identified a judicial mission linked to text and to the democratic process. It is a crucial element of the "ballot-box democracy" paradigm of public law, one of the four categories of public law presented in the Introduction to this volume. This theory of judicial review can largely be seen as a device for rehabilitating the Supreme Court and refuting charges of ideological partisanship and the "counter-majoritarian" difficulty (Bickel, 1962). It has been tremendously influential in both the courts and in legal scholarship. For instance, based on a close reading of the papers of the members of the Court, Elizabeth Bussiere has argued that in the late 1960 and early 1970s, the progressive Warren Court stopped short of recognizing a right to welfare-the kind of positive right that is recognized by some European courts-because of the doctrinal legacy of Carolene Products and the double standard that had been created for social and economic rights, on the one hand, and civil and political rights, on the other hand (Bussiere, 1997: 99-101; 1999). To illustrate the approach taken by the academy, take the work of the influential legal scholar John Hart Ely. In 1980, he famously defended the Warren Court's criminal procedure and social rights jurisprudence against charges of Lochner-style judicial activism on the grounds that the Warren Court had been faithful to Carolene Products and had sought to further "'participational' goals of broadened access to the process and bounty of representative government" (1980: 75).

Returning specifically to courts and administration, procedural rationality review was quite clearly informed by the larger constitutional context of Carolene Products. With the fading of confidence in administrative expertise, the fear of regulatory capture, and the rise of new social movements, courts were called upon in the 1960s to take a more active role in the 
regulatory process. Safeguarding a general sphere of liberty was anathema in legal discourse. Instead, consistent with the democracy-enhancing theory of public law more generally, courts responded with the interest representation model of the administrative process and the requirement that in the course of the rulemaking proceeding agencies carefully articulate why their policy choices further the statutory framework enacted by the legislature. Although American judicial activism is common to both my analysis and the theory reviewed in the previous section, the emphasis of the two accounts is somewhat different: in adversarial legalism and rational-choice theory, the principal engine of judicial activism is Congressional legislation, while in the present account it is legal doctrine and judicial philosophy.

On the European side, the historiography is not nearly as extensive. In contrast with the United States, however, there appears to be significant continuity between the liberal theories that animated late-nineteenth-century and early-twentieth-century public law and the theories that inform contemporary public law. This is evident in the doctrinal histories of proportionality and equality, both of which are traced to nineteenth-century and early-twentieth-century sources. Why there is rupture in the American case and continuity in the European case is the question. At least in part, the answer appears to rest in the different European experience of courts and elected bodies in the early years of democracy and the institutional reputations that emerged from those events. European public law has been deeply marked by the history of authoritarianism and collaboration in the inter-war years and World War II (Linz and Stepan, 1978; Capoccia, 2005). In contrast with the United States, the experience of the new democracies of the time demonstrated that elections and parliamentary regimes could give rise to immense instability and could make way for authoritarian regimes. Such regimes were established not by military coups but by formally democratic procedures that put into place dictators and that abolished the political freedoms of the earlier democratic regime. The celebration of majoritarian democracy and the directly elected branches, so apparent in post-Lochner jurisprudence, was at odds with the European inter-war experience. A certain suspicion of democracy and an awareness of the need to safeguard rights, even in the face of democratic procedures, is evident across a number of areas of constitutional law, and has also influenced judicial review in the area of social and economic policymaking (Shapiro and Stone Sweet, 1994; Capoccia, 2013). 
At the same time, courts emerged as a central feature of the European post-war architecture. These were primarily newly established constitutional courts but also included preexisting administrative courts, both of which were cast as safeguarding a set of higher-level principles, including an extensive set of individual liberties, in the operation of the political and social order. Why public law courts took on this role is something of a puzzle. Courts, like parliaments, did not sport a stellar record during the 1930s and 1940s. In many cases, the ordinary courts and administrative courts were complicit in enforcing and in some cases stretching the law to deprive Jews, Communists, and other groups of their private rights and, for those employed in public administration, their civil service status (Fabre, 2001; Joerges and Ghaleigh, 2003). In the republican ideology of the French Revolution, which was influential not only in France but also much of the Continent, courts were regarded with suspicion and parliaments were cast as the principal mouthpiece of the people and the general will. On the other hand, even taking into account administrative courts, powers of judicial review in the interwar period were very limited, and therefore courts could not be tainted to the same extent as parliaments by their involvement with authoritarian or collaborationist regimes. Setting aside these questions, the fact remains that the political elites that emerged after World War II regarded constitutional and administrative courts and liberty-driven supervision of all branches of government as a fundamental safeguard for their newly established democratic orders.

To conclude this discussion of the two theories of judicial review, let us consider some of their implications specifically for regulatory governance. To begin with, it is important to acknowledge that proceduralized rationality and fundamental rights can overlap to some extent. In other words, they can operate as what is known in comparative law scholarship as "functional equivalents" (Zweigert and Kötz, 1998: 44). The types of claims that are advanced in European litigation involving economic and social rights are often litigated and adjudicated in the context of proceduralized rationality review in the American system. For instance, the claim that the regulatory means adopted to accomplish the public purpose were inappropriate, familiar from proportionality, or the claim that an agency unfairly burdened one group to the benefit of another, familiar from equality, are often raised in American litigation alleging that the agency rule was arbitrary and capricious or that the rulemaking procedure was inadequate. To illustrate, 
in the textbook case of Nova Scotia Food Products, the litigant (a whitefish processor) challenged an agency rule requiring that all smoked fish be heated to high temperatures to protect against food poisoning on the grounds that it was "arbitrary and capricious." 37 The litigant argued that the temperature requirement was unnecessary to achieve food safety in the case of whitefish since whitefish did not carry the same risk of botulism as other types of fish and the safety of whitefish could be guaranteed through alternative means such as salting. The whitefish processor also claimed that the agency had failed to take into account the special characteristics of whitefish processors as compared with other types of processors and to treat them differently as warranted by their different situations. The court of appeals did not reach the arbitrary and capricious challenge but held in favor of the litigant on the related grounds that the agency procedure was defective since it had failed to answer the litigant's objections in the "concise general statement of basis and purpose" at the conclusion of the rulemaking procedure. ${ }^{38}$ In other words, equality and the necessity component of proportionality, centerpieces of European fundamental rights, were advanced and adjudicated in the context of American proceduralized rationality review.

Even though there is a certain degree of functional equivalence, there are also important respects in which the conceptual differences between the two types of judicial review give rise to differences in legal practice. First, American proceduralized rationality review attaches great importance to the formal status of the regulatory norm. If it is enacted by the legislature, then the court cannot intervene because the ballot box and legislative politics are seen as the best guarantor of a democratic policymaking process. If, on the other hand, the regulatory norm is adopted by administrative authorities, then proceduralized rationality review applies. By contrast, European liberty review applies equally to all types of state action, legislative and administrative. Indeed, in systems which afford easy access to constitutional courts, the incentive is to concentrate efforts on challenging the legislative framework, not the implementing rules. Litigants often take this path because constitutional doctrine requires that parliamentary lawnot administrative rules - limit rights and any court victory striking law will be more durable given

\footnotetext{
${ }^{37}$ U.S. v. Nova Scotia Food Products Corp., 417 F. Supp. 1364, 1372-74 (E.D.N.Y. 1976), rev'd, 568 F.2d 240, 245 (2d Cir. 1977).

${ }^{38}$ U.S. v. Nova Scotia Food Products Corp., 568 F.2d at 252-53.
} 
the political and practical hurdles to re-writing legislation. The overall result is that the legislative component of regulatory governance is subject to more extensive judicial oversight in Europe. German cases like the Pharmacy Case $e^{39}$ or the Smoking Ban Case ${ }^{40}$ would fail or, more likely, never be brought in the American system.

The second notable difference produced by the two models of judicial review concerns the way in which courts assess the reasoning of administrative agencies and the hardship imposed by regulatory policies. In European legal thinking, when courts strike government regulatory policies based on proportionality, equality, or any of the other doctrines mentioned earlier, they are guaranteeing respect for the law, understood not in the statutory, positivist sense but as the higher law of rights and duties fundamental to any liberal democratic order. They are not, in the doctrinal discourse, interfering with administrative discretion, which is left to the administration to carry out in line with the parliamentary will and the general interest and, for the most part, falls outside of the purview of courts. This characterization of judicial review stands in contrast with American legal thinking, which generally frames judicial decisions striking agency policy decisions as policing the exercise of administrative discretion. Associated with this conceptual difference is a difference in how cases are decided on judicial review. On the European side, the tendency is to interfere in absurd cases in which the reasons are patently flimsy or the hardship imposed on certain groups appears to be entirely out of proportion with the overall purposes of the regulatory framework. On the American side, the emphasis is on carefully scrutinizing every element of the case for administrative action -the empirical studies, the interpretation of the enabling statute, and merits of the different policy options-to ensure that it stands up to the many objections made by the participants in the administrative proceeding. If, however, the policy survives this analysis then it is irrelevant whether the government has unfairly singled out certain social or market actors and no amount of hardship will lead to reversal of the regulatory outcome. Thus the types of cases that survive or fail judicial review are likely to differ between the two systems.

\footnotetext{
${ }^{39}$ BVerfG, June 11, 1958, 7 BVerfGE 377.

${ }^{40}$ BVerfG, June 11, 2008, 121 BVerfGE 317.
} 
This comparative assessment of the types of challenges to regulatory policymaking that are viable before the courts raises the question of how the difference is related to the contrast presented in the previous section. In both classifications, the American system is contrasted with European jurisdictions. But the adversarial legalism theory also posits American courts as exceptionally powerful in the regulatory process: more legal challenges are brought to courts and the courts are more activist in reviewing government policies. Do the forms of judicial review presented in this section - proceduralized rationality versus fundamental rights - contribute to this judicial activism? At first glance, the difference does not logically support such an outcome. Because it affects the legislative component of regulatory schemes and because of the balancing dimension of many of its doctrinal tests, the fundamental rights model could easily be construed as giving courts more license to interfere with the regulatory process. Therefore, it may be worthwhile revisiting some of the empirical claims of the adversarial legalism hypothesis. As explained earlier, adversarial legalism is a sweeping concept that encompasses all aspects of the regulatory state. It may be true that the fragmented American system outsources more regulatory activities to private litigants and courts and therefore the system overall is more litigious than European regulatory systems. But if Congress decides to delegate regulatory policymaking to a classic bureaucracy then it may be that judicial intervention is as, or even more, deferential than judicial intervention in European legal systems. To understand whether this is the case, it will be necessary to conduct carefully designed comparisons of different policy areas which take into account both constitutional and administrative law and which examine data recent enough to capture the growing importance of constitutional litigation in Europe.

If, however, as some of the anecdotal evidence suggests, American courts are indeed readier to strike regulatory policymaking than European courts, then it is plausible to suggest a relationship between the doctrinal theory and levels of court activism. It may be that the requirements of full public participation in the administrative process and comprehensive analysis in line with a close reading of the statutory framework are more burdensome than the fundamental rights paradigm of judicial review. Although rights affect all state action, including legislation, the fact is that most regulatory statutes must be implemented by administrative regulations. When those regulations are challenged in court, it might be that the exhaustive 
procedure and reason-giving required of American agencies is more burdensome than the reasons required of European bodies to trump rights. If true, it bears underscoring the irony of such an outcome: American doctrinal thinking on economic and social rights was driven by the desire to prevent courts from striking regulatory programs but the democracy-enhancing alternative (the ballot-box paradigm) may have served to legitimate even more judicial activism. Again, to understand whether such a connection exists, it will be necessary to conduct carefully designed comparative studies that capture the types of legal doctrines that are used by courts in different jurisdictions to strike regulatory policymaking. It will also be necessary to take into account the socio-legal insight that institutional and historical context, as well as or even more so than positive law and doctrinal constructs, are important for understanding judicial behavior.

Without knowing whether and how the two theories of judicial review affect the level of court activism, it is difficult to reach any conclusions regarding their relative merits. It is important to note, however, that the normative question has become highly salient with the global diffusion of regulatory governance (Levi-Faur, 2005) and public law (Ginsburg, 2008) and can only be expected to become more so as the globalization process unfolds over time. The ramifications and opportunities for learning are especially significant for newer democracies. There is a growing trend in favor of empowering constitutional courts (Lamprea et al., this volume). Thus new democracies are likely to follow the path of rights-driven judicial review. At the same time, there is also good reason to think that the American model will serve as a source of transplants to other jurisdictions (Yackee, this volume; Zaring, this volume). Whether and how these two models will be combined and layered is an open question. At this stage, it suffices to note that any lessons to be garnered from the United States and Europe should be informed by the relative competence of courts, bureaucracies, and legislatures in their particular political and cultural settings.

\section{CONCLUSION}

Judicial review of the administrative state has served as a fertile source of comparative law scholarship for well over a century. In contrast with some areas of comparative law, which focus 
on similar functional needs across legal systems and seek to promote convergence, the literature on judicial review has tended to focus on broad-brush differences between legal systems, the historical origins of those differences, and how those differences can inform critical thinking on the domestic practice of judicial review. This chapter has explored two of the most important contrasts that have been drawn: between the common law and the droit administratif and between a proceduralized and adversarial policy process and an informal and discretionary one. It has also identified a third divide: between judicial review designed to safeguard the economic and social rights most directly implicated by the administrative state and judicial review dedicated to preserving democracy in the operation of the bureaucracy.

In addition to analyzing the differences and their historical origins, this chapter has drawn out the consequences of the three classifications of judicial review specifically for the regulatory function of the administrative state. It is helpful to summarize them here. The spread of regulatory governance is associated with certain types of instruments and institutions of government: the elaboration of formal rules to regulate private markets, the enforcement of the rules against market actors, and the allocation of extensive powers to administrative authorities to carry out the various tasks of regulatory governance. The differences in judicial review traced in this chapter bite most at the rule-development as opposed to the rule-enforcement phase of the policymaking cycle. Although it can be notoriously difficult to distinguish between the two, as a general matter, the enforcement of rules, in contrast with rulemaking, requires individualized fact-finding to determine whether the terms of the regulatory program are applicable. The procedures followed by administrative authorities to find individualized facts and the judicial review of such administrative determinations do not differ significantly among the jurisdictions considered in this chapter (Bignami, 2004; cf. Asimow, 2015). These administrative determinations - whether designed to culminate in a money fine, the granting or suspension of a license, or something else-tend to be heavily proceduralized in view of due process rights and the interest in reaching a fair and accurate determination. Judicial review of the outcome seeks to guarantee respect for the various administrative procedures and to assess the plausibility of the factual determinations made by the administrative authority. Even though there continues 
to be variation, especially between common law and droit administratif jurisdictions, their practical implications have faded considerably over time.

Turning to the policymaking and rulemaking activities of the regulatory state, this chapter has argued that there are indeed significant differences in judicial review. Although standing is relatively easy to establish in the Conseil d'Etat, as compared with common law courts, it may be more difficult to succeed on the merits of an individual challenge because of the Conseil d'Etat's involvement in both rulemaking and judicial review. In American adversarial legalism, the policymaking process in bureaucracies is heavily proceduralized, and regulated parties and other types of litigants frequently go to court to challenge both the procedure and the substantive determinations of administrative agencies. By contrast, administrative authorities in European jurisdictions are not significantly constrained by judicially enforced procedure when developing new rules. Judicial review in Europe focuses on the burdens imposed by regulatory choices on economic rights and, in some cases, social rights, and employs the legal doctrines of proportionality and equality to assess the legitimacy of those burdens, whether imposed by the legislature or the bureaucracy. In the United States, judicial review is driven by a concern for safeguarding democracy when power is delegated to bureaucracies. It does so with legal doctrines designed to ensure pluralist, participatory administrative process and comprehensive administrative rationality tethered to the enabling legislation. These important differences serve as a springboard for mapping judicial review and for understanding how courts across the world intervene in the regulatory process.

\section{BIBLIOGRAPHY}

Ackerman, Bruce. 1998. We the People: vol. 2; Transformations. Cambridge, MA: The Belknap Press of Harvard University Press.

Allison, J.W.F. 1996. A Continental Distinction in the Common Law: A Historical and Comparative Perspective on English Public Law. Oxford: Oxford University Press.

Asimow, Michael. 2015. "Five Models of Administrative Adjudication," 63 American Journal of Comparative Law 3-31. 
Baer, Susanne. 2012. "Equality," in Michel Rosenfeld and András Sajó, eds., The Oxford Handbook of Comparative Constitutional Law. Oxford: Oxford University Press.

Barak, Aharon. 2012. Proportionality: Constitutional Rights and Their Limitations. Translated by Doron Kalir. New York: Cambridge University Press.

Bell, John. 2010. “From 'Government Commissioner' to 'Public Reporter': A Transformation in the French Administrative Court Procedure," 16 European Public Law 533-38.

Bickel, Alexander. 1962. The Least Dangerous Branch: The Supreme Court at the Bar of Politics. Indianapolis, IN: Bobbs-Merrill.

Bignami, Francesca. 2004. "Three Generations of Participation Rights Before the European Commission," 68 Law and Contemporary Problems 61-84.

Bignami, Francesca. 2011. "From Expert Administration to Accountability Network: A New Paradigm for Comparative Administrative Law," 59 American Journal of Comparative Law 859907.

Bignami, Francesca. 2012. "Comparative Administrative Law," in Mauro Bussani and Ugo Mattei, eds., The Cambridge Companion to Comparative Law. Cambridge: Cambridge University Press.

Bignami, Francesca, and R. Daniel Kelemen. Forthcoming. "Kagan's Atlantic Crossing: Adversarial Legalism, Eurolegalism and Cooperative Legalism in European Regulatory Style," in Jeb Barnes and Thomas F. Burke, eds., The Politics of Legalism. New York: Routledge

Bignami, Francesca, and Carla Spivack. 2014. "Social and Economic Rights as Fundamental Rights," 62 American Journal of Comparative Law 561-87.

Breyer, Stephen. 1995. Breaking the Vicious Circle: Toward Effective Risk Regulation. Cambridge, MA: Harvard University Press.

Breyer, Stephen G., Richard B. Stewart, Cass R. Sunstein, and Matthew L. Spitzer. 2002. Administrative Law and Regulatory Policy: Problems, Text, and Cases. $5^{\text {th }}$ ed. New York: Aspen Law \& Business.

Brown, Neville Lionel, and John Bell. 1998. French Administrative Law. $5^{\text {th }}$ ed. Oxford: Oxford University Press.

Brown, Neville L., and J.F. Garner. 1967. French Administrative Law. London: Butterworths.

Bussiere, Elizabeth. 1997. (Dis)Entitling the Poor: The Warren Court, Welfare Rights, and the American Political Tradition. University Park, PA: Pennsylvania State University Press. 
Bussiere, Elizabeth. 1999. "The Supreme Court and the Development of the Welfare State: Judicial Liberalism and the Problem of Welfare Rights," in Cornell W. Clayton and Howard Gillman, eds., Supreme Court Decision-Making: New Institutionalist Approaches. Chicago: University of Chicago Press.

Cane, Peter. 2009. Administrative Tribunals and Adjudication. Oxford: Hart Publishing. Capoccia, Giovanni. 2005. Defending Democracy: Reactions to Extremism in Interwar Europe. Baltimore, MD: Johns Hopkins University Press.

Capoccia, Giovanni. 2013. "Militant Democracy: The Institutional Bases of Democratic SelfPreservation," 9 Annual Review of Law and Social Sciences 207-26.

Cassese, Sabino. 2010. I/ Diritto Amministrativo: Storia e Prospettive. Milano: Giuffrè Editore.

Currie, David P. 1989. "Lochner Abroad: Substantive Due Process and Equal Protection in the Federal Republic of Germany," 1989 Supreme Court Review 333-72.

Dicey, A.V. 1885. Lectures Introductory to the Study of the Law of the Constitution. London: Macmillan and Co.

Ely, John Hart. 1980. Democracy and Distrust: A Theory of Judicial Review. Cambridge, MA: Harvard University Press.

Epstein, David, and Sharyn O'Halloran. 1994. “Administrative Procedures, Information, and Agency Discretion," 38 American Journal of Political Science 697-722.

Epstein, David, and Sharyn O'Halloran. 1999. Delegating Powers: A Transaction Cost Politics Approach to Policy Making under Separate Powers. Cambridge: Cambridge University Press.

Ertman, Thomas. 1997. The Birth of Leviathan. Cambridge: Cambridge University Press.

Fabre, Philippe. 2001. Le Conseil d'Etat et Vichy: Le Contentieux de L'Antisémitisme. Paris: Publications de la Sorbonne.

Fromont, Michel. 2006. Droit administratif des États européens. Paris: Presses Universitaires de France.

Garner, James W. 1924. “French Administrative Law,” 33 Yale Law Journal 597-627.

Gillman, Howard. 1993. The Constitution Besieged: The Rise and Demise of Lochner Era Police Powers Jurisprudence. Durham, NC: Duke University Press.

Ginsburg, Tom. 2008. "The Global Spread of Constitutional Review," in Keith E. Whittington, R. Daniel Kelemen, and Gregory A. Caldeira, eds., The Oxford Handbook of Law and Politics. Oxford: Oxford University Press. 
Goodnow, Frank J. 1893. Comparative Administrative Law: An Analysis of the Administrative Systems, National and Local, of the United States, England, France and Germany. Vol. I. New York and London: G.P. Putnam's Sons.

Grimm, Dieter. 2007. "Proportionality in Canadian and German Constitutional Jurisprudence," 52 University of Toronto Law Journal 383-97.

Horwitz, Morton J. 1992. The Transformation of American Law, 1870-1960: The Crisis of Legal Orthodoxy. Oxford: Oxford University Press.

Huber, John D., and Charles R. Shipan. 2002. Deliberate Discretion? The Institutional Foundations of Bureaucratic Autonomy. New York: Cambridge University Press.

Jensen, Christian B., and Robert J. McGrath. 2011. "Making Rules About Rulemaking: A Comparison of Presidential and Parliamentary Systems," 64 Political Research Quarterly 656-67.

Joerges, Christian, and Navraj Singh Ghaleigh. 2003. Darker Legacies of Law in Europe: The Shadow of National Socialism and Fascism over Europe and its Legal Traditions. Oxford: Hart Publishing.

Kagan, Robert A. 1991. "Adversarial Legalism and American Government," 10 Journal of Policy Analysis and Management 369-406.

Kagan, Robert A. 1994. "Do Lawyers Cause Adversarial Legalism? A Preliminary Inquiry," 19 Law and Social Inquiry 1-62.

Kagan, Robert A. 1997. "Should Europe Worry About Adversarial Legalism?" 17 Oxford Journal of Legal Studies 165-84.

Kagan, Robert A. 2001. Adversarial Legalism: The American Way of Law. Cambridge, MA: Harvard University Press.

Kelemen, R. Daniel. 2011 Eurolegalism: The Transformation of Law and Regulation in the European Union. Cambridge, MA: Harvard University Press.

Kommers, Donald P., and Russell A. Miller. 2012. The Constitutional Jurisprudence of the Federal Republic of Germany. $3^{\text {rd }}$ ed. Durham, NC: Duke University Press.

Latour, Bruno. 2010. The Making of Law: An Ethnography of the Conseil d'Etat. Translated by Marina Brilman and Alain Pottage. Cambridge: Polity Press.

Ledford, Kenneth, F. 2004. "Formalizing the Rule of Law in Prussia," 37 Central European History 203-24.

Lerche, Peter. 1961. Übermaß und Verfassungsrecht. Zur Bindung des Gesetzgebers an die Grundsätze der Verhältnismäßigkeit und der Erforderlichkeit. Cologne: Carl Heymanns. 
Letsas, George. 2006. "Two Concepts of the Margin of Appreciation," 26 Oxford Journal of Legal Studies 705-32.

Leventhal, Harold. 1974. "Environmental Decisionmaking and the Role of the Courts," 122 University of Pennsylvania Law Review 509-55.

Levi-Faur, David. 2005. "The Global Diffusion of Regulatory Capitalism," 598 Annals of the American Academy of Political \& Social Science 12-32.

Lindseth, Peter. 2005. "'Always Embedded' Administration: The Historical Evolution of Administrative Justice as an Aspect of Modern Governance," in Christian Joerges, Bo Stråth, and Peter Wagner, eds., The Economy as a Polity: The Political Constitution of Contemporary Capitalism. London: UCL Press.

Linz, Juan J., and Alfred Stepan. 1978. The Breakdown of Democratic Regimes: Europe. Baltimore, MD: Johns Hopkins University Press.

Long, Marceau, Prosper Weil, Guy Braibant, Pierre Delvolvé, and Bruno Genevois. 2013. Les grands arrêts de la jurisprudence administrative. $13^{\text {th }}$ ed. Paris: Dalloz.

Lovell, Colin Rhys. 1962. English Constitutional and Legal History: A Survey. Oxford: Oxford University Press.

Mannori, Luca, and Bernardo Sordi. 2001. Storia del diritto amministrativo. Roma: Editori Laterza.

Mashaw, Jerry L. 2012. Creating the Administrative Constitution: The Lost One Hundred Years of American Administrative Law. New Haven, CT: Yale University Press.

Mathews, Jud, and Alec Stone Sweet. 2011. "All Things in Proportion? American Rights Review and the Problem of Balancing," 60 Emory Law Journal 797-875.

Mattarella, Bernardo Giorgio. 2010. "Administrative Law in Italy: An Historical Sketch," 4 Rivista trimestrale di diritto pubblico 1009-54.

Maurer, Hartmut. 2009. Allgemeines Verwaltungsrecht. $17^{\text {th }}$ ed. München: Verlag.

Mayer, David N. 2009. "Substantive Due Process Reconsidered: The Rise and Fall of Liberty of Contract," 60 Mercer Law Review 564-658.

Mayer, Otto. 1904. Le droit administratif allemand: Partie speciale. Vol. 2. Paris: V. Giard \& E. Brière.

McCubbins, Matthew D., Roger G. Noll, and Barry R. Weingast. 1987. "Administrative Procedures as Instruments of Political Control," 3 Journal of Law and Economics 243-77. 
McCubbins, Matthew D., Roger G. Noll, and Barry R. Weingast. 1989. "Structure and Process, Politics and Policy: Administrative Arrangements and the Political Control of Agencies," 75 Virginia Law Review 431-82.

Merrill, Thomas W. 2011. "Article III, Agency Adjudication, and the Origins of the Appellate Review Model of Administrative Law," 111 Columbia Law Review 939-1002.

Mitchell, J.D.B. 1965. "The Causes and Effects of the Absence of a System of Public Law in the United Kingdom," Public Law 95-118.

Moe, Terry M., and Michael Caldwell. 1994. "The Institutional Foundations of Democratic Government: A Comparison of Presidential and Parliamentary Systems," 150 Journal of Institutional \& Theoretical Economics 171-95.

Morand-Deviller, Jacqueline. 2013. Cours de droit administratif. $13^{\text {th }}$ ed. Paris: LGDJ, Lextenso éditions.

Olson, Mancur. 1965. The Logic of Collective Action: Public Goods and the Theory of Groups. Cambridge, MA: Harvard University Press.

Robson, W.A. 1928. Justice and Administrative Law. London: Macmillan.

Rose-Ackerman, Susan. 1995. Controlling Environmental Policy. New Haven, CT: Yale University Press.

Rose-Ackerman, Susan, Stefanie Egidy, and James Fowkes. 2015. Due Process of Lawmaking: The United States, South Africa, Germany and the European Union. Cambridge: Cambridge University Press.

Schwartz, Bernard. 1949. Law and the Executive in Britain: A Comparative Study. New York: New York University Press.

Shapiro, Martin M., and Alec Stone Sweet. 1994. "The New Constitutional Politics of Europe," 26 Comparative Political Studies 397-421.

Singh, Mahendra P. 2001. German Administrative Law in Common Law Perspective. Berlin: Springer.

Stewart, Richard B. 1975. "The Reformation of American Administrative Law," 88 Harvard Law Review 1669-813.

Stigler, George J. 1971. "The Theory of Economic Regulation," 2 Bell Journal of Economics and Management Science 3-21.

Stigler, George J. 1974. "Free Riders and Collective Action: An Appendix to Theories of Economic Regulation," 5 Bell Journal of Economics and Management Science 359-65.

Stolleis, Michael. 2001. Public Law in Germany, 1800-1914. New York: Berghahn Books. 
Stone, Alec. 1992. The Birth of Judicial Politics in France. Oxford: Oxford University Press.

Strøm, Kaare. 2003. "Parliamentary Democracy and Delegation," in Kaare Strøm, Wolfgang C. Müller, and Torbjörn Bergman, eds., Delegation and Accountability in Parliamentary Democracies. Oxford: Oxford University Press.

Sunstein, Cass R. 1985. "Interest Groups in American Public Law," 38 Stanford Law Review 2987.

Thies, Michael F. 2001. "Keeping Tabs on Partners: The Logic of Delegation in Coalition Governments," 45 American Journal of Political Science 580-98.

Tridimas, Takis. 2006. The General Principles of EU Law. $2^{\text {nd }}$ ed. Oxford: Oxford University Press.

Van Caenegem, R.C. 1988. The Birth of the English Common Law. $2^{\text {nd }}$ ed. Cambridge: Cambridge University Press.

Vogel, David. 1986. National Styles of Regulation: Environmental Policy in Great Britain and the United States. Ithaca, NY: Cornell University Press.

von Krauss, Rupprecht. 1955. Der Grundsatz der Verhältnismäßigkeit. In seiner Bedeutung für die Notwendigkeit des Mittels im Verwaltungsrecht. Hamburg: Appel.

Wright, Benjamin F. 1942. The Growth of American Constitutional Law. New York: Houghton Mifflin.

Zaring, David. 2010. “Reasonable Agencies," 96 Virginia Law Review 135-97.

Zoller, Elisabeth. 2008. Introduction to Public Law: A Comparative Study. Leiden: Martinus Nijhoff Publishers.

Zweigert, Konrad, and Hein Kötz. 1998. Introduction to Comparative Law. $3^{\text {rd }}$ rev. ed. Translated by Tony Weir. Oxford: Clarendon Press. 